COMPETITOR: Jurnal Pendidikan Kepelatihan Olahraga

Volume 12 Nomor 1, Februari 2020

e-ISSN: 2657-0703 dan p-ISSN: 2085-5389

(c) (1) This work is licensed under a Creative Commons Attribution

4.0 International License

\title{
METODE MENGAJAR DAN MOTIVASI TERHADAP HASIL BELAJAR KETERAMPILAN SERVIS FLAT TENIS LAPANGAN (STUDI EKSPERIMEN PADA MAHASISWA FIK UNM MAKASSAR)
}

\author{
Hasbunallah AS ${ }^{1}$, Ahmad Rum Bismar ${ }^{2}$
}

Keywords :

Teaching Methods;

Motivation; flat Tennis

Service.

\section{Corespondensi Author \\ ${ }^{1}$ Pendidikan Jasmani}

Kesehatan dan Rekreasi,

Universitas Negeri Makassar.

Hasbunallah.as@unm.ac.id

${ }^{2}$ Pendidikan Kepelatihan

Olahraga, Universitas Negeri

Makassar.

ahmad.rum.bismar@unm.ac.id

\section{Article History}

Received: Desember 2019;

Reviewed: Januari 2020;

Accepted: Januari 2020;

Published: Februari 2020

\section{ABSTRACT}

The aim of this experimental study was to determine the effect of all teaching methods, part, mixed and motivation result learning toward of flat service skill courts tennis. Learning motivation is divided into two parts, namely high andlow. This research was conducted at Faculty of Sport Science State University of Macassar,the academic year 2014/2015. Experimental using factorial design method 2x3. The sample consisted of 60 students were divided into 6 groups, each consisting of 10 students. Data analysis technique is a two-way analysis of variance (ANOVA) followed by Tukey's test at a significance level of $\alpha=0.05$. The results of this study indicate that ( (1) overall teaching methods higher effect of the part teacing methods on learning outcomes flat tennis service skills (2) overall teaching methods lower effect of the part teacing methods on learning outcomes flat tennis service skills, (3) overall teaching methods lower effect of the part teacing methods on learning outcomes flat tennis service skills, (4) there is interaction between the overall teaching methods, part teaching methods and combined teaching methods and learning motivation outcomes flat tennis service skills,(5) overall teaching methods higher effect of the part teacing methods on learning outcomes flat tennis service skills using a high learning motivation, (6) overall teaching methods lower effect of the part teacing methods on learning outcomes flat tennis service skills using a high learning motivation, (7) part teaching methods lower effect of the combined teacing methods on learning outcomes flat tennis service skills using a high learning motivation, (8) overall teaching methods higher effect of the part teacing methods on learning outcomes flat tennis service skills using a low learning motivation, (9) overall teaching methods lower effect of the part teacing methods on learning outcomes flat tennis service skills using a low learning motivation, (10) part teaching methods lower effect of the combined teacing methods on learning outcomes flat tennis service skills using a low learning motivation.

\section{ABSTRAK}

Penelitian eksperimental ini bertujuan untuk mengetahui pengaruh metode mengajar dan motivasi belajar terhadap hasil belajar servis flat tenis lapangan. Motivasi belajar terbagi menjadi dua bagian yaitu tinggi dan rendah. Penelitian ini dilaksanakan di Fakultan Ilmu Keolahragaan Universitas Negeri Makassar Propinsi 
Sulawesi Selatan, tahun akademik 2014/2015. Metode eksperimen menggunakan desain faktorial 2x3. Sampel terdiri dari 60 mahasiswa dibagi menjadi 6 kelompok, masing-masing terdiri dari 10 mahasiswa. Teknik analisis data adalah dua-arah analisis varians (ANOVA) dan dilanjutkan dengan uji Tukey pada tingkat signifikansi $\alpha=0.05$. Hasil penelitian ini menunjukkan bahwa (1). Metode mengajar keseluruhan lebih tinggi pengaruhnya dari metode mengajar bagian terhadap hasil belajar keterampilan servis flat tenis lapangan, (2) Metode mengajar keseluruhan lebih rendah pengaruhnya dari metode mengajar gabungan terhadap hasil belajar keterampilan servis flat tenis lapangan, (3) Metode mengajar bagian lebih rendah pengaruhnya dari metode mengajar gabungan terhadap hasil belajar keterampilan servis flat tenis lapangan, (4) Terdapat interaksi antara metode mengajar keseluruhan, metode mengajar bagian, metode mengajar gabungan dan motivasi terhadap hasil belajar keterampilan servis flat tenis lapangan, (5) Metode mengajar keseluruhan lebih tinggi dari metode mengajar bagian terhadap hasil belajar keterampilan servis flat tenis lapangan pada kelompok motivasi tinggi, (6) Metode mengajar keseluruhan lebih rendah dari metode mengajar gabungan terhadap hasil belajar keterampilan servis flat tenis lapangan pada kelompok motivasi tinggi, (7) Metode mengajar bagian lebih rendah dari metode mengajar gabungan terhadap hasil belajar keterampilan servis flat tenis lapangan pada kelompok motivasi tinggi, (8) Metode mengajar keseluruhan lebih tinggi dari metode mengajar bagian terhadap hasil belajar keterampilan servis flat tenis lapangan pada kelompok motivasi rendah, (9) Metode mengajar keseluruhan lebih rendah dari metode mengajar gabungan terhadap hasil belajar keterampilan servis flat tenis lapangan pada kelompok motivasi rendah, dan (10) Metode mengajar bagian lebih rendah dari metode mengajar gabungan terhadap hasil belajar keterampilan servis flat tenis lapangan pada kelompok motivasi rendah.

\section{PENDAHULUAN}

Pencapaian prestasi optimal dalam bidang olahraga merupakan dambaan bagi setiap atlit, namun untuk mencapai hal tersebut perlu perencanaan yang matang melalui suatu system pembinaan terpadu sistematis dan berkesinambungan. Seiring dengan laju pembangunan bangsa yang sedang berlangsung sampai sekarang ini, pembangunan bidang olahraga di Indonesia diarahkan untuk mencapai cita-cita bangsa yaitu terbentuknya manusia Indonesia seutuhnya yang sehat jasmani maupun rohani, serta terampil sehingga mampu berprestasi dalam bidang olahraga guna mengangkat harkat, martabat dan derajat bangsa. Perhatian pemerintah ditujukan kepada usaha penyebarluasan kegiatan olahraga sebagaicara pembinaan kesehatan jasmani dan rohani bagi setiap anggota masyarakat. Mencermati hal tersebut, pemerintah telah mensyahkan UndangUndang Republik Indonesia Nomor 3 Tahun 2005 tentang Sistem Keolahragaan Nasional, bahwa system pembinaan olahraga harus dilakukan melalui 3 (tiga) pilar yaitu; olahraga pendidikan, olahraga rekreasi, dan olahraga prestasi.

Olahraga adalah bagian integrasi dari proses pendidikan yang merupakan arena pedagogis dibidang gerak dan pengalaman gerak. Upaya untuk mencapai prestasi olahraga dilakukan dalam bentuk latihan, pengajaran olahraga sebagai kegiatannya. Latihan-latihan yang diberikan harus berorientasi pada tujuan yang ingin dicapai dan dinyatakan dengan perubahan tingkah laku yang bersifat menyeluruh. Keterampilan- 


\section{e-ISSN: 2657-0703 dan p-ISSN: 2085-5389}

keterampilan tersebut hanya dapat dimiliki melalui suatu proses belajar gerak. Fakultas Ilmu Keolahragaan (FIK) adalah Lembaga Pendidikan Tenaga Kependidikan bidang keolahragaan bagi calon guru pendidikan jasmani dan lembaga pendidika non kependidikan di bidang olahraga. Lembaga ini berperan sebagai pencetak tenaga kependidikan yang kompeten dan profesional dalam bidang pendidikan jasmani dan pelatih olahraga untuk mencapai tujuan olahraga yaitu berprestasi tinggi di bidang keolahragaan.

Dalam prestasi belajar maupun prestasi latihan pada semua cabang olahraga tidak hanya ditentukan oleh penguasaan teknikteknik dasar saja, tetapi juga dipengaruhi oleh kemampuan dan kesiapan kondisi fisik yang dibutuhkan untuk kegiatan olahraga yang bersangkutan. Penguasaan keterampilan tenis lapangan memiliki persyaratan kesiapan kondisi fisik untuk dapat menguasai berbagai teknik dasar dan kemampuan bermain. Kondisi fisik yang dibutuhkan untuk olahraga tenis lapangan, antara lain adalah kekuatan, kecepatan, kelentukan, daya tahan, daya ledak (power), keseimbangan dan koordinasi

Pada kenyataannya menurut pengamatan dalam beberapa turnamen sebagian besar pemain Indonesia tersisih di babak pertama dibandingkan dengan pemain Internasional. Secara teknik kualitas pukulan belum memadai, terutama kurang maksimalnya pukulan servis yang dimiliki. Pukulan servis yang mereka lakukan sangat mudah dikembalikan oleh lawan dan juga banyak melakukan servis yang salah (fault), artinya melakukan servis tidak tepat pada kotak servis sebagai sasaran.

Dalam permainan tenis lapangan, servis merupakan pukulan paling penting. Servis adalah awal dari permainan, tetapi bagi pemain top dunia servis bisa langsung mendapatkan point melalui ace servis. Dalam permainan tenis lapangan, pemain yang melakukan servis keras selain harus memiliki tinggi badan yang cukup, juga harus mengetahui bagaimana cara mendapatkan tenaga dan cara menggunakan gerak pecut.

$$
\text { Menurut Agusalim (2007 }
$$

Permainan tenis lapangan adalah salah satu permainan yang dikategorikan dalam permainan bola kecil dan sangat banyak digemari masyarakat karena terkandung banyak unsur kegembiraan dan sangat menggairahkan untuk dilakukan. Berbagai tingkat usia dapat melakukan dan menikmati permainan ini baik pria maupun wanita karena olahraga ini tidak ada bahaya benturan badan waktu bermain dan masingmasing pemain dapat mengatur cara dan tingkat permainan sesuai dengan kemampuan serta kekuatan dan kecepatannya sendiri. Agus Salim menyatakan bahwa: Tenis lapangan dimainkan sebagai kompetisi olahraga tingkat tinggi dan berkelas dunia, namun perkembangan tersebut tetap tidak mengubah sebuah kenyataan bahwa permainan atau olahraga ini sangat tinggi untuk rekreasi dan bergembira atau sebagai media untuk kebugaran badan. Keterampilan mengandung arti pelaksanaan yang cepat dalam penyelesaian tugas gerak itu dalam waktu yang minimum. Semakin cepat pelaksanaan suatu gerak, tanpa mengorbankan hasil akhir (kualitas) yang diharapkan, maka akan membuat terakuinya keterampilan orang yang bersangkutan. Keterampilan adalah kesanggupan menggunakan pengetahuan seseorang secara efektif dan secara siap dalam pelaksanaan, serta mencapai kemantapan dari suatu keberhasilan dalam mencapai suatu tujuan. Hal ini dapat diartikan bahwa keterampilan gerak seseorang pada tingkat tertentu, mampu bergerak dengan mudah bergerak, luwes, dan dapat mengatasi masalah-masalah lingkungannya. Menurut Ricard Magill (2011 : 3) seseorang dikatakan terampil apabila memiliki kemampuan untuk memperagakan suatu tugas gerak dengan kualitas hasil gerak yang baik (cepat, cermat dan tepat). Untuk individu yang terampil dalam melakukan suatu tugas gerak akan nampak halus, dan luwes sehingga aktivitas gerak yang dilakukan efektif dan efisien. Keterampilan adalah suatu kegiatan atau tugas yang memiliki tujuan tertentu atau tujuan untuk mencapai indikator kualitas kinerja

Menurut Agus Mahendra (2007:273-275) Metode megajar keseluruhan merupakan bentuk latihan keterampilan yang pelaksanaannya dilakukan secara utuh dari keterampilan yang dipelajari. Dalam metode keseluruhan, pemain dituntut melakukan gerakan keterampilan yang dipelajari secara keseluruhan. Apabila keterampilan olahraga yang diajarkan itu sifatnya sederhana dan mudah dimengerti maka keterampilan tersebut diajarkan secara keseluruhan, dan 


\section{Volume 12 Nomor 1, Februari 2020}

setiap teknik bagian hanya dilatih secara khusus apabila pemain atau subyek selalu membuat kesalahan pada teknik bagian tersebut. Metode keseluruhan memberikan keuntungan maksimal jika yang dipelajari ialah gerakan yang sederhana. Dilain pihak Agus Mahendra menyatakan bahwa: Metode keseluruhan atau whole method adalah suatu metode mengajar yang beranjak dari yang umum ke yang khusus. Dalam mengajarkan keterampilan gerak atau permainan, maka bentuk yang utuh atau keseluruhan diajarkan terlebih dahulu kemudian dipecah-pecahkan menjadi bagian-bagian. Metode mengajar bagian merupakan bentuk latihan keterampilan yang dilakukan secara bagian per bagian dari keterampilan gerak yang dipelajari. Bentuk keterampilan gerak yang dipelajari dipilah-pilah ke dalam bentuk gerakan yang lebih mudah dan sederhana. Teori belajar Gestalt mengenalkan suatu pendekatan organisasi terhadap stimulusrespons (S-R). S-R yang merupakan bagianbagian dari suatu keterampilan, diorganisir menjadi suatu bentuk keseluruhan

Menurut Winarno (1994) Metode Bagian - Keseluruhan (Part - Whole Methode) metode ini merupakan metode gabungan dari keseluruhan dan bagian.Metode part and whole merupakan metode pembelajaran yang dilakukan secara bertahap, dari pengenalan/pembelajaran teknik bagian hingga gabungan dari keseluruhan teknik bagian yang merupakan teknik gerakan yang utuh Metode part and whole merupakan metode pembelajaran yang dilakukan secara bertahap, dari pengenalan/pembelajaran teknik bagian hingga gabungan dari keseluruhan teknik bagian yang merupakan teknik gerakan yang utuh

Menurut Djaali (2008:101) Motivasi merupakan faktor penting di dalam memahami perilaku manusia termasuk didalam memahami hubungan dengan manusia yang lain. Dan motivasi merupakan konsep hipotesis untuk suatu kegiatan yang dipengaruhi oleh persepsi dan tingkah laku seseorang untuk merubah situasi yang tidak memuaskan atau tidak menyenangkan.

Motivasi merupakan proses psikis yang mendorong orang untuk melakukan sesuatu. Motivasi dapat berasal dari dalam diri maupun luar diri seseorang. Jadi motivasi dimulai dari adanya perubahan energi dalam pribadi.Perubahan-perubahan dalam motivasi timbul dari perubahan-perubahan tertentu di dalam organisme manusia, misalnya karena terjadi perubahan dalam sistem pencernaan maka timbulnya motif lapar

METODE PENELITIAN Metode dan Desain Penelitian

Tabel 1.

Rancangan penelitian desain faktorial $2 \mathrm{X} 3$

\begin{tabular}{|c|c|c|c|}
\hline Motivasi (B) & $\begin{array}{c}\text { Keseluruhan } \\
\text { (A1) }\end{array}$ & $\begin{array}{c}\text { Bagian } \\
\text { (A2) }\end{array}$ & $\begin{array}{c}\text { Gabungan } \\
\text { (A3) }\end{array}$ \\
\hline Tinggi (B1) & A1B1 & A2B1 & A3B1 \\
\hline Rendah (B2) & A1B2 & A2B2 & A3B2 \\
\hline Total & A1 & A2 & A3 \\
\hline
\end{tabular}

\section{Keterangan :}

A

$\mathrm{B}=$ kelompok motivasi

$\mathrm{A}_{1} \quad=$ kelompok metode mengajar keseluruhan

$\mathrm{A}_{2} \quad=$ kelompok metode mengajar bagian

$\mathrm{A}_{3}=$ kelompok metode mengajar gabungan

$\mathrm{A}_{1} \mathrm{~B}_{1} \quad=$ kelompok metode mengajar keseluruhan dengan menggunakan kelompok 


\section{e-ISSN: 2657-0703 dan p-ISSN: 2085-5389}

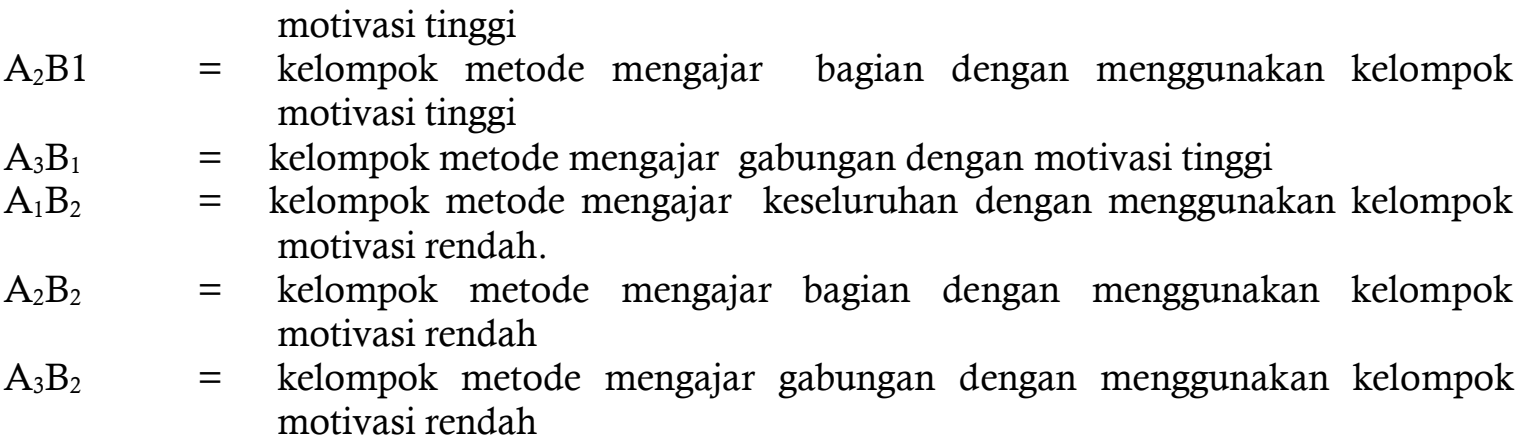

Populasi target dalam penelitian ini adalah seluruh mahasiswa putra FIK UNM Program Studi Pendidikan Kepelatihan yang belum memprogramkan dan mengikuti mata kuliah tenis lapangan berjumlah 200 0rang. Penentuan sampel penelitian dilakukan dengan teknik Randomized group design, yaitu dengan cara 200 orang diacak dan diambil 120 orang sampel. Kemudian dari 120 sampel tersebut diacak kembali untuk menentukan masing-masing 40 orang sampel. Jumlah murid laki-laki sebanyak 60 siswa yang terbagi ke dalam 6 sel, masing-masing sel berjumlah 10 orang Dengan demikian terbentuk 6 (enam) sel dari ketiga kelompok metode mengajar tersebut yakni: (1) Kelompok metode mengajar keseluruhan dengan tingkat motivasi tinggi (A1B1), (2) Kelompok metode mengajar keseluruhan dengan tingkat motivasi rendah (A1B2), (3) Kelompok metode mengajar bagian dengan tingkat motivasi tinggi (A2B1), (4) Kelompok metode mengajar bagian dengan tingkat motivasi rendah (A2B2), (5) Kelompok metode mengajar gabungan dengan tingkat motivasi tinggi (A3B1), dan (6) Kelompok metode mengajar gabungan dengan tingkat motivasi rendah (A3B2). Teknik pengumpulan data yang dilakukan mengacu kepada variabel-variabel yang terlibat dalam penelitian ini, yakni: (1) Untuk data variabel terikat di dapat melalui tes penilaian proses gerak keterampilan teknik servis flat tenis lapangan, (2) untuk data variabel atribut didapat melalui tes motivasi. Teknik yang digunakan dalam menganalisis data adalah teknik analisis varian (ANAVA) dua arah dengan taraf signifikansi $\alpha=0,05$. Persyaratan yang diperlukan dalam analisis varian adalah uji normalitas dengan menggunakan uji Liliefors, dan uji homogenitas dengan menggunakan uji Barlett, dan dilanjutkan dengan uji Tukey jika terdapat interaksi. Teknik analisis data menggunakan SPSS Versi 20

\section{HASIL DAN PEMBAHASAN}

Hasil penelitian yang dikemukakan adalah sebagai berikut: (1) terdapat perbedaan pengaruh metode mengajar keseluruhan dengan metode mengajar bagian terhadap hasil belajar keterampilan servis flat tenis lapangan mahasiswa FIK UNM, diperoleh perbedaan nilai rata-rata atau nilai $\mathrm{Q}$-hitung 5,100 dan $\mathrm{Q}_{\text {-tabel }} 2,95$, terdapat perbedaan yang nyata sig (p) lebih kecil dari $0,05(0,025$ $<0,05)$, untuk terlihat pada tabel kolom Sig (p) adalah 0,025 , atau probabilitas jauh di bawah $\alpha 0,05$. Sehingga dapat diambil keputusan bahwa tolak $\mathrm{H}_{0}$ dan terima $\mathrm{H}_{1}$. Jadi dapat disimpulkan bahwa terdapat perbedaan hasil belajar keterampilan servis flat pada permainan tenis lapangan antara kelompok metode mengajar keseluruhan dengan kelompok metode mengajar bagian pada mahasiswa FIK UNM. (2) terdapat perbedaan pengaruh metode mengajar keseluruhan dengan metode mengajar gabungan terhadap hasil belajar keterampilan servis flat tenis lapangan mahasiswa FIK UNM, diperoleh perbedaan nilai rata-rata atau nilai $\mathrm{Q}_{\text {-hitung }}=-5,250$ dan $\mathrm{Q}_{\text {-tabel }}$ 2,95, terdapat perbedaan yang nyata sig (p) lebih kecil dari $0,000(0,000<0,05)$, untuk terlihat pada tabel kolom Sig (p) adalah 0,000 , atau probabilitas jauh di bawah $\alpha 0,05$. Sehingga dapat diambil keputusan bahwa tolak $\mathrm{H}_{0}$ dan terima $\mathrm{H}_{1}$. Jadi dapat disimpulkan bahwa terdapat perbedaan hasil belajar keterampilan servis flat pada permainan tenis lapangan antara kelompok metode mengajar keseluruhan dengan kelompok metode mengajar gabungan pada mahasiswa FIK UNM. (3) terdapat perbedaan pengaruh metode mengajar bagian dengan metode 


\section{Volume 12 Nomor 1, Februari 2020}

mengajar gabungan terhadap hasil belajar keterampilan servis flat tenis lapangan mahasiswa FIK UNM, diperoleh perbedaan nilai rata-rata atau nilai $Q$-hitung $-10,350$ dan $\mathrm{Q}$ tabel 2,95 , terdapat perbedaan yang nyata sig (p) lebih kecil dari 0,000 $(0,000<0,05)$, untuk terlihat pada tabel kolom Sig (p) adalah 0,000, atau probabilitas jauh di bawah $\alpha$ 0,05. Sehingga dapat diambil keputusan bahwa tolak $\mathrm{H}_{0}$ dan terima $\mathrm{H}_{1}$. Jadi dapat disimpulkan bahwa terdapat perbedaan hasil belajar keterampilan servis flat pada permainan tenis lapangan antara kelompok metode mengajar bagian dengan kelompok metode mengajar gabungan pada mahasiswa FIK UNM. (4) Terdapat interaksi antara metode mengajar keseluruhan, metode mengajar bagian, metode mengajar gabungan dan motivasi terhadap hasil belajar keterampilan servis flat tenis lapangan hal ini dibuktikan dengan perolehan $\mathrm{F}_{\text {hitung }}$ sebesar 6,012. Jika dibandingkan $F_{\text {hitung }}$ lebih besar dari $F_{\text {tabel }},\left(F_{\text {hitung }} 6,012>F_{\text {tabel }} 3,17\right)$, dengan demikian dapat diambil keputusan bahwa tolak $\mathrm{H}_{0}$ dan terima $\mathrm{H}_{1}$. Jadi dapat disimpulkan bahwa terdapat interaksi antara metode mengajar keseluruhan, bagian, gabungan dan motivasi terhadap hasil belajar keterampilan servis flat pada permainan tenis lapangan pada mahasiswa FIK UNM. (5) terdapat perbedaan antara metode mengajar keseluruhan dan metode mengajar bagian pada kelompok pemain yang memiliki motivasi tinggi terhadap hasil belajar keterampilan servis flat tenis lapangan mahasiswa FIK UNM, diperoleh perbedaan nilai rata-rata atau nilai $Q_{\text {-hitung }}-10,800$ dan $Q$ tabel 4,9 , terdapat perbedaan yang nyata sig (p) lebih kecil dari 0,000 $(0,000<0,05)$, untuk terlihat pada tabel kolom Sig (p) adalah 0,000, atau probabilitas jauh di bawah $\alpha 0,05$. Sehingga dapat diambil keputusan bahwa tolak $\mathrm{H}_{0}$ dan terima $\mathrm{H}_{1}$. Jadi dapat disimpulkan bahwa terdapat perbedaan hasil belajar keterampilan servis flat pada permainan tenis lapangan antara kelompok metode mengajar keseluruhan dengan kelompok metode mengajar bagian bagi mahasiswa yang memiliki motivasi tinggi pada mahasiswa FIK UNM. (6) tidak terdapat perbedaan antara metode mengajar keseluruhan dan metode mengajar gabungan pada kelompok pemain yang memiliki motivasi tinggi terhadap hasil belajar keterampilan servis flat tenis lapangan mahasiswa FIK UNM, diperoleh perbedaan nilai rata-rata atau nilai $\mathrm{Q}_{\text {-hitung }}$ 2,500 dan $\mathrm{Q}$ tabel 3,15 . Sedangkan pada uji signifikansi tidak terdapat perbedaan yang nyata karena signifikansinya lebih besar dari 0,05 atau $(0,959>0,05)$, untuk terlihat pada tabel kolom Sig (p) adalah 0,959, atau probabilitas jauh di diatas nilai $\alpha 0,05$. Sehingga dapat diambil keputusan bahwa tolak $\mathrm{H}_{1}$ dan terima $\mathrm{H}_{0}$. Jadi dapat disimpulkan bahwa tidak terdapat perbedaan hasil belajar keterampilan servis flat pada permainan tenis lapangan antara kelompok metode mengajar keseluruhan dengan kelompok metode mengajar gabungan bagi mahasiswa yang memiliki motivasi tinggi pada mahasiswa FIK UNM. (7) terdapat perbedaan antara metode mengajar bagian dan metode mengajar gabungan yang memiliki motivasi tinggi terhadap hasil belajar keterampilan servis flat tenis lapangan mahasiswa FIK UNM, diperoleh perbedaan nilai rata-rata atau nilai $Q_{\text {-hitung }}$ 13,300 dan $Q_{\text {-tabel }}$ 3,15. Sedangkan pada uji signifikansi terdapat perbedaan yang nyata sig (p) lebih kecil dari 0,005 atau $(0,000<0,05)$, untuk terlihat pada tabel kolom Sig (p) adalah 0,000 , atau probabilitas jauh di bawah $\alpha 0,05$. Sehingga dapat diambil keputusan bahwa tolak $\mathrm{H}_{0}$ dan terima $\mathrm{H}_{1}$. Jadi dapat disimpulkan bahwa terdapat perbedaan hasil belajar keterampilan servis flat pada permainan tenis lapangan antara kelompok metode mengajar bagian dengan kelompok metode mengajar gabungan bagi mahasiswa yang memiliki motivasi tinggi pada mahasiswa FIK UNM. (8) terdapat perbedaan antara metode mengajar keseluruhan dan metode mengajar bagian pada kelompok pemain yang memiliki motivasi rendah terhadap hasil belajar keterampilan servis flat tenis lapangan mahasiswa FIK UNM, diperoleh perbedaan nilai rata-rata atau nilai $Q_{\text {-hitung }}-10,500$ dan Qtabel 3,15. Sedangkan pada uji signifikasi terdapat perbedaan yang nyata sig $(\mathrm{p})$ lebih kecil dari $0,005(0,001<0,05)$, untuk terlihat pada tabel kolom Sig (p) adalah 0,001, atau probabilitas jauh di bawah nilai $\alpha 0,05$. Sehingga dapat diambil keputusan bahwa tolak $\mathrm{H}_{0}$ dan terima $\mathrm{H}_{1}$. Jadi dapat disimpulkan bahwa terdapat perbedaan hasil belajar keterampilan servis flat pada permainan tenis lapangan antara kelompok 


\section{e-ISSN: 2657-0703 dan p-ISSN: 2085-5389}

metode mengajar keseluruhan dengan kelompok metode mengajar bagian bagi mahasiswa yang memiliki motivasi rendah pada mahasiswa FIK UNM. (9) tidak terdapat perbedaan antara metode mengajar keseluruhan dan metode mengajar gabungan pada kelompok pemain yang memiliki motivasi rendah terhadap hasil belajar keterampilan servis flat tenis lapangan mahasiswa FIK UNM, diperoleh perbedaan nilai rata-rata atau nilai $Q$-hitung $-4,600$ dan $\mathrm{Q}$ tabel 3,15. Pada uji signifikansi terdapat perbedaan yang nyata sig (p) lebih kecil dari $0,05(0,431>0,05)$, untuk terlihat pada tabel kolom Sig (p) adalah 0, 000, atau probabilitas jauh di atas $\alpha 0,05$. Sehingga dapat diambil keputusan bahwa terima $\mathrm{H}_{1}$ dan tolak $\mathrm{H}_{0}$. Jadi dapat disimpulkan bahwa terdapat perbedaan hasil belajar servis flat pada permainan tenis lapangan antara kelompok metode mengajar keseluruhan dengan kelompok metode mengajar gabungan bagi mahasiswa yang memiliki motivasi rendah pada mahasiswa FIK UNM dan (10) tidak terdapat perbedaan antara metode mengajar bagian dan metode mengajar gabungan yang memiliki motivasi rendah terhadap hasil belajar keterampilan servis flat tenis lapangan mahasiswa FIK UNM, diperoleh perbedaan nilai rata-rata atau nilai Q-hitung 5,900 dan Qtabel 3,15 , sedangkan pada uji signifikansi tidak terdapat perbedaan yang nyata sig (p) lebih besar dari 0,05 $(0,942>0,05)$, untuk terlihat pada tabel kolom Sig (p) adalah 0,942, atau probabilitas jauh di atas $\alpha 0,05$. Sehingga dapat diambil keputusan bahwa tolak $\mathrm{H}_{1}$ dan terima $\mathrm{H}_{0}$. Jadi dapat disimpulkan bahwa tidak terdapat perbedaan hasil belajar keterampilan servis flat pada permainan tenis lapangan antara kelompok metode mengajar bagian dengan kelompok metode mengajar gabungan bagi mahasiswa yang memiliki motivasi rendah pada mahasiswa FIK UNM.

\section{SIMPULAN DAN SARAN}

Dari hasil pengujian hipotesis dan pembahasan hasil penelitian, dapat ditarik kesimpulan sebagai berikut : (1) Metode mengajar keseluruhan lebih tinggi pengaruhnya dari metode mengajar bagian terhadap hasil belajar keterampilan servis flat tenis lapangan pada kelompok mahasiswa, (2) Metode mengajar keseluruhan lebih rendah pengaruhnya dari metode mengajar gabungan terhadap hasil belajar keterampilan servis flat tenis lapangan pada kelompok mahasiswa, (3) Metode mengajar bagian lebih rendah pengaruhnya dari metode mengajar gabungan terhadap hasil belajar keterampilan servis flat tenis lapangan pada kelompok mahasiswa, (4) Terdapat interaksi antara metode mengajar keseluruhan, metode mengajar bagian, metode mengajar gabungan dan motivasi terhadap hasil belajar keterampilan servis flat tenis lapangan, (5) Metode mengajar keseluruhan lebih tinggi dari metode mengajar bagian terhadap hasil belajar keterampilan servis flat tenis lapangan pada kelompok motivasi tinggi, (6) Metode mengajar bagian lebih rendah dari metode mengajar gabungan terhadap hasil belajar keterampilan servis flat tenis lapangan pada kelompok motivasi tinggi, dan (7) Metode mengajar keseluruhan lebih rendah dari metode mengajar bagian terhadap hasil belajar keterampilan servis flat tenis lapangan pada kelompok motivasi rendah.

Dari kesepuluh hipotesis penelitian yang diajukan terdapat 3 (tiga) hipotesis penelitian yang ditolak, yaitu: hipotesis enam, kesembilan dan kesepuluh yaitu: 6) tidak terdapat perbedaan pengaruh yang signifikan antara metode mengajar keseluruhan dan metode mengajar gabungan terhadap hasil belajar keterampilan servis flat tenis lapangan motivasi belajar tinggi, 9) tidak terdapat perbedaan pengaruh yang signifikan antara metode mengajar keseluruhan dan metode mengajar gabungan terhadap hasil belajar keterampilan servis flat tenis lapangan motivasi rendah, 10) tidak terdapat perbedaan pengaruh yang signifikan antara metode mengajar bagian dan metode mengajar gabungan terhadap hasil belajar keterampilan servis flat tenis lapangan motivasi rendah.

Berdasarkan kesimpulan hasil penelitian dan implikasi sebagaimana diuraikan di atas maka diketengahkan saransaran sebagai berikut:

1. Karena secara keseluruhan metode mengajar gabungan telah menunjukkan keunggulan. sebagai sebuah metode mengajar dalam meningkatkan hasil belajar keterampilan servis flat tenis lapangan mahasiswa dibanding dengan metode mengajar bagian dan metode mengajar keseluruhan maka bagi para dosen, guru, pelatih, peneliti, dan 
mahasiswa dianjurkan untuk memanfaatkan hasil penelitian ini dalam rangka meningkatkan hasil belajar keterampilan servis flat tenis lapangan. Dengan kata lain metode mengajar gabungan dapat dijadikan sebagai pedoman pengajaran dalam proses belajar mengajar, khususnya metode mengajar yang mempunyai karakterisatik yang sama dengan meningkatkan hasil belajar keterampilan servis flat tenis lapangan mahasiswa, selain itu juga disarankan untuk mempertimbangkan faktor motivasi dalam proses belajar mengajar.

2. Perlunya dilakukan penelitian lanjutan dengan menambahkan variabel dan memilih variabel kategori atau atribut yang lainnya.

3. Penelitian ini dilakukan terhadap mahasiswa putera FIK UNM Program Studi Pendidikan Kepelatihan Olahraga yang belum memprogramkan dan mengikuti mata kuliah tenis lapangan dan tidak melibatkan mahasiswa puteri. Karena meningkatkan hasil belajar keterampilan servis flat tenis lapangan diperlukan juga oleh mahasiswa puteri, maka sebaiknya juga dilakukan penelitian serupa dengan menggunakan sampel puteri.

\section{DAFTAR RUJUKAN}

Djaali (2008). Psikologi Pendidikan. Jakarta: PT Bumi Aksara. 2008.

Magill.A.Richard. (2011). Motor Learning and Control. Ninth Ed. New York: McGrawHill.

Mahendra..Agus. (2007). Modul Teori Belajar Mengajar Motorik. Bandung: FPOK UPI Bandung.

Undang-Undang Republik Indonesia Nomor 3 Tahun 2005.

Undang-Undang Nomor 20 Tahun 2003 tentang Sistem Pendidikan; Dalam Undang-Undang R.I. Nomor 12 Tahun 2012 Bandung : Citra Umbara.2012.

Usman. Husaini. (2009). Manajemen: Teori Praktik dan Riset Pendidikan. Jakarta: PT Bumi Aksara. 